\author{
CRISTINA GODUN \\ (iD) https://orcid.org/0000-0002-0018-4511 \\ Uniwersytet $w$ Bukareszcie \\ Bukareszt
}

\title{
Od Biegunów \\ do Prowadź swój pług przez kości umarłych \\ - kilka uwag dotyczących recepcji fabularnego świata Olgi Tokarczuk w Rumunii
}

\author{
From Flights to Drive Your Plow over the Bones of the Dead \\ - some remarks on the reception of the world of \\ Olga Tokarczuk's fiction in Romania
}

\begin{abstract}
This paper presents the most important aspects of the reception of four novels by Olga Tokarczuk translated into Romanian, on the basis of reviews published in the Romanian literary press. The topics addressed most frequently by Romanian reviewers include the topos of journey, the contemporary human condition within the framework of everyday life, the axiological system of Olga Tokarczuk's narrative world, the rich imagination, the fragmentary narrative, and the tendency to cross interdisciplinary boundaries. An amazing imagination, an exceptional literary talent, surprising combinations and multifaceted protagonists are only some of the elements of Olga Tokarczuk's writing praised by Romanian reviewers. Tokarczuk's novels are appreciated in Romania due to both the relevance of their themes, however uncomfortable they might be, and their great ability to translate such tough topics into literature.
\end{abstract}

Key words: reception, narrative strategy, world of fiction

Olga Tokarczuk (ur. 1962) w Rumunii była dobrze znana miłośnikom literatury jeszcze przed przyznaniem jej Literackiej Nagrody Nobla, ponieważ na język rumuński już wcześniej przetłumaczono te powieści pisarki, które przyniosły jej jednomyślne uznanie krytyków oraz czytelników z całego świata i dzięki którym uważa się ją za artystkę obdarzoną wyjątkowym talentem ${ }^{1}$, tj.:

${ }^{1}$ Umiejętność opowiadania historii, sprawiających wrażenie, że dotyczą one każdego z nas, szerokie horyzonty myślowe, a zarazem proste, otwarte podejście sprawiły, iż Tokarczuk do- 
Podróż ludzi ksiegi (Călătoria oamenilor cărții, Polirom, 2001), Prawiek i inne czasy (Străveacul și alte vremi, Polirom, 2002), Bieguni (Rătăcitorii, Art, 2013; Polirom, 2018), Dom dzienny, dom nocny (Casă de zí, casă de noapte, Casa Cărții de Știință, 2017), Ostatnie historie (Ultimele povestiri, Polirom, 2018), Prowadź swój pług præ̌ez. kości umarlych (Poartă-ți plugul peste oasele morților, Polirom, 2019). Mimo iż w 2019 roku Olga Tokarczuk dość często pojawiała się na łamach rumuńskiej prasy literackiej (nowe przekłady, recenzje ostatnich tłumaczeń, fragmenty powieści publikowane w gazetach i na blogach literackich), przyznanie jej Nagrody Nobla poskutkowało jeszcze większą popularnością pisarki i jej utworów, co widoczne było w różnych sferach². W niniejszym artykule chciałabym zaprezentować echa recepcji powieści Bieguni, Dom dzienny, dom nocny, Ostatnie historie i Prowadź swój plug pręez kości umarlych w rumuńskiej przestrzeni kulturowej oraz przedstawić kilka uwag na temat narracyjnego świata autorki, które jako tłumaczka odnotowałam w kronikach literackich (Godun 2013; 2018; 2019). Rumuńscy krytycy, omawiając twórczość Olgi Tokarczuk, często podejmują takie tematy, jak pojawiający się w jej powieściach topos podróży, kondycja współczesnego człowieka, widzianego w codziennych sytuacjach, system aksjologiczny zawarty w jej dziełach, bogata wyobraźnia artystki i skłonność do przekraczania granic dyscyplin oraz umiejętność harmonizowania eklektycznych idei w jedna, spójną całość 3 .

W chwili ukazania się powieści Bieguni Olga Tokarczuk cieszyła się już uznaniem rumuńskich czytelników, którzy podziwiali jej erudycję i umiejętność snucia opowieści oraz budowania narracji harmonijnie łączącej mistycyzm, mitologię, motywy psychologiczne i oniryczne, atmosferę baśniowości i sceny z życia codziennego - wszystkie te elementy świata przedstawionego sytuuja prozę pisarki w obszarze realizmu magicznego. Do najczęściej omawianych zagadnień w kontekście powieści Bieguni należą strategia narracyjna zastosowana przez Tokarczuk oraz forma, która przybiera narracja. Pisarka

czekała się od rumuńskich recenzentów wielu wzniosłych epitetów, takich jak: „Szeherezada”, „povestaşă stranie” (tj. niezwykła bajarka), „scriitoare aproape-clasică-în-viață” (współczesna pisarka prawie klasyczna) (Sora 2017) czy „,fată dragă a literaturii polone şi universale” (ukochana dziewczyna literatury polskiej i światowej) (zob. Cărtărescu 2002, 5).

2 Mam tu na myśli m.in. audycje radiowe, dyskusje na łamach prasy, prezentacje książek, wieczory autorskie organizowane przez księgarnie i kluby książki, rozmowy z tłumaczami dzieł Olgi Tokarczuk, wywiady pisarki udzielone przy okazji wcześniejszych wizyt w Rumunii, różne dyskusje literackie (jak na przykład zorganizowaną 22 listopada 2019 roku podczas targów książki „Gaudeamus” w Bukareszcie Literatura polonă în actualitate. Olga Tokarczuk) itd.

3 Wskazuję tu zaledwie kilka z najciekawszych kwestii podnoszonych w recenzjach powieści Olgi Tokarczuk przetłumaczonych na język rumuński, zob. Nicolae 2019; Muntean 2019. 
nie tworzy powieści $\mathrm{w}$ tradycyjnym rozumieniu; wychodząc na przeciw oczekiwaniom czytelników, proponuje formę powieści konstelacyjnej czy powieści-monografii pewnego fenomenu. Bieguni to powieść mozaikowa mixtum compositum (Stăvaru 2019) - zbiór ponad stu historii, w których epicki czas zaprzecza linearności, dialogi są niemal nieobecne, fragmenty prozy poetyckiej przeplatają się z narracją typu eseistycznego, z naukowymi wynurzeniami na temat sztuk plastycznych, anatomii i anatomopatologii. Intryga jest warstwowa, ale wszystkie narracyjne nici łączy wspólny wątek - podróż w rozmaitych postaciach. Podróż jako fenomen współczesnej kultury. Podróż jako sposób poznania... prawdy, życia, „ja” w stosunku do świata i ,ja” w stosunku do samego siebie. Podróż jako odwołanie do kondycji ludzkiej. Ale też podróż jako bunt, ratunek, syndrom. Ów topos, wokół którego jak kawałki puzzli układają się liczne historie, odzwierciedla wewnętrzny świat autorki: Olga Tokarczuk mówi o sobie i o tym, jak ona sama patrzy na świat. Jeśli nawet wszystkie opowieści i zapiski o kronikarskim charakterze, które współtworzą Biegunów, nie układają się w jedną historię i nie maja jednego wspólnego bohatera, to i tak dają wymowny obraz współczesnego człowieka: nadaktywnego, pozbawionego korzeni, niespokojnego, człowieka będącego w ciagłym ruchu, jakby uciekającego od siebie.

W Biegunach podróż odbywa się w dwóch określonych wymiarach i kierunkach, które się ze sobą przecinają mamy tu podróż w przestrzeni fizycznej po horyzontalnej osi czasu i linearnej osi przestrzeni, rządzonej prawami świata fizycznego, oraz podróż w przestrzeni duchowej po osi wertykalnej. Bieguni to zbiór opowieści, których nie sposób złożyć w całość podczas pierwszej lektury. Fragmentaryczna, pozornie chaotyczna budowa sprzyja lekturze, jako że powieść może być czytana na wyrywki, a nie tylko linearnie. W Biegunach podróż jest nie tyle motywem literackim, co antropologicznym, kulturowym, społecznym; stanowi parabolę życia człowieka i drogi, którą musi on przebyć. Nie jest to jednak cel nadrzędny. Najważniejszy jest ruch jako opozycja wobec sedentaryzmu. Podróż jest w zasadzie formą ucieczki od siebie samego, od własnych niepokojów i niepowodzeń, jest poszukiwaniem na zewnątrz równowagi i celu w życiu.

Ten główny motyw fikcyjnego świata Olgi Tokarczuk oraz układ na linii fizyczność - duchowość nie został w pełni wyczerpany w Biegunach. Jego kontynuację (choć w innej postaci) odnajdziemy w Ostatnich historiach. Dzieło to jest wzruszająca, zatomizowaną opowieścią o trzech zwykłych kobietach, poszukujących szczęścia i spełnienia, których biografie stanowią ontologiczne radiografie ich duszy. Podobnie jak w poprzednich utworach, tak i tu 
Tokarczuk daje się poznać jako świetna portrecistka; w Ostatnich historiach tworzy złożone sylwetki kobiece - silne, niezależne, o bogatym wnętrzu i dobrze nakreślonej filozofii życiowej. Są to postacie niemal archetypowe niemal, ponieważ metamorfozy, którym poddaje je narracja, wewnętrzny monolog i dialog z siłami świata zewnętrznego okradaja je z niezmienności, sprawiaja, że nieustannie ewoluuja na drodze do samopoznania i nie zamykają ich w hermetycznych formach, lecz otwierają je na uniwersalność. Podróż Idy do własnej heterotopii jako świętego miejsca odrodzenia duchowego rozpoczyna się w chwili, gdy wysiada ona z zepsutego samochodu i znajduje pomoc u dwóch staruszków, którzy prowadzą schronisko dla bezdomnych zwierzat, porzuconych przez właścicieli. Tutaj kończy się podróż Idy w przestrzeni fizycznej, ustępując miejsca podróży wewnętrznej do własnej istoty i własnej przeszłości, na które bohaterka spogląda z nowej perspektywy. Rzeczywistość splata się ze snem i pamięcią w grę chimer, a granica między tym, co realne, a tym, co wyimaginowane, jest bardzo cienka. Podobnie jak w większości utworów Olgi Tokarczuk, tak i tu ujawnia się skłonność autorki do podkreślania wagi świadomości ludzkiej i rozpatrywania z perspektywy wielokulturowej ważkich tematów, takich jak śmierć, cierpienie czy kruchość istoty ludzkiej. Autorka ujmuje je w sposób polifoniczny, z różnych punktów widzenia. Przykładowo, śmierć nie tylko jest nieunikniona, nie jest jedynie procesem czysto biologicznym, ale jest również fenomenem kulturowym, społecznym, duchowym i dydaktycznym, umożliwia ukazanie życia człowieka w szerszej perspektywie.

Dla Mai podróż ma również funkcję katartyczną, oczyszczająca. Podróż w planie fizycznym, którą Maja postrzega jako iluzję, ma w rzeczywistości odpowiednik w planie duchowym. Bohaterka poszukuje bowiem równowagi i sensu w życiu. Jak słusznie zauważa magik Kisz, Maja ucieka, a nie podróżuje; ucieka od własnego życia do zamarzniętego, północnego miasteczka, ucieka od iluzji życia osobistego, od mężczyzny, który jej nie chce, od towarzystwa innych ludzi, z obawy przed zapuszczeniem korzeni w jednym miejscu. Maja czuje, że jest inna, nie ma poczucia przynależności do ludzi, którzy prowadzą osiadły tryb życia, tych, którzy biorą w posiadanie ziemię i gospodarują na niej; widzi więcej niż pozwala na to ułuda życia codziennego.

Kiedyś punktem fokalnym życia każdego człowieka była rodzina, czyli dom. Teraz dla każdego z nas może to być coś innego. I nieraz zdarza się tak, że wolność rozumiana jest jako możliwość ciagłego ruchu, podróży, oswajania przestrzeni. Współczesny człowiek często nie potrafi przekroczyć barier iluzji, którą tworzy rzeczywistość. Stosunkowo późno uzmysławia so- 
bie, że życie na ziemi to tylko jeden ze sposobów realizacji wyższego „ja” poprzez codzienne doświadczenia i wiedzę, do której ma dostęp dzięki oderwaniu się od form znanych z przestrzeni domowej. Celem podróży, w której uczestniczy współczesny człowiek, jest potrzeba poznania, nawiązania kontaktu z innymi ludźmi, ale też z rzeczami oraz miejscami, z żywą energia świata zewnętrznego. Gdy czytamy, że Tokarczuk pociaga „wszytko, co popsute, niedoskonałe, ułomne, pęknięte, (...) formy byle jakie, pomyłki w dziele stworzenia, ślepe zaułki, (...) wszystko, co odstaje od normy, co jest za małe albo za duże, wybujałe lub niepełne, monstrualne i odrażające" (Tokarczuk 2007, 20), przychodzi nam na myśl Andrzej Stasiuk i jego obsesja na punkcie wszystkiego, co nie jest takie, jak być powinno, tego, co jest w rozkładzie, w rozpadzie - jak wynika z Jadac do Babadag. „Błędów w dziele tworzenia" autorka nie szuka tylko w świecie fizycznym, w tym, co nas otacza, ale i w ludzkiej anatomii. Podróż do wnętrza ciała człowieka daje czytelnikom wgląd do fascynującego świata ludzkich narządów; odkrywa nieznany, tajemniczy świat, który wzbudza ciekawość. Kruchość i tajemniczość ludzkiego ciała, ,tego efemerycznego wehikułu, który przenosi nas w przestrzeń i w czas, zawsze poddawanego, jak wszystko co jest unikalne, przerażającemu zagrożeniu destrukcji” (Cojocaru 2019), uwidacznia się w opowieściach o doktorze Blau, Frederiku Ruyschu i córce Charlotty, o Angelu Solimanie, wiedeńskim masonie z XVIII wieku, a najbardziej w biografii Holendra Filipa Verheyena, jednego z ojców współczesnej anatomii i odkrywcy ścięgna Achillesa. Fascynująca opowieść o podróży holenderskiego uczonego w głąb anatomii własnej kończyny i wzruszające Listy do mojej amputowanej nogi tworzą jedną z najpiękniejszych i najciekawszych biografii, jakie możemy przeczytać w Biegunach. Zresztą fascynacja ciałem człowieka i złożonością ludzkiej anatomii przejawia się również w innych utworach noblistki (por. Dom dżienny, dom nocny, Ostatnie historie oraz Prowadź swój plug pržez. kości umarlych).

Podróż w głąb mikrokosmosu człowieczego ciała, po którym jesteśmy oprowadzeni „mapą szczegółowo sporządzoną” (Cojocaru 2019), to temat stale obecny w twórczości Tokarczuk, powracający niemal obsesyjnie, gnostycznie w każdej jej powieści. W Ostatnich historiach ludzkie ciało jest nie tyle źródłem fascynacji i objawienia, daje raczej asumpt do refleksji na temat krótkotrwałości materii i kruchości życia, co wprowadza czytelnika na wyższe poziomy świadomości. Dla Idy serce to „monstrualny zlepek mięsistych tasiemek, gumowych i sprężystych”, które pulsuje „w rytmie kopulacyjnym” (Tokarczuk 2004, 41), narząd, który utrzymuje ciało ludzkie przy życiu i na 
którym upływ czasu pozostawia nieusuwalne ślady. Przenikamy tu do cudownego świata anatomii dzięki „poetyckiej radiografii skomplikowanych wnętrzności i fizjologii kobiecej" (Dinu 2019), których odpowiednikiem jest metafora domu jako świątyni ducha, którą odnajdujemy w Domu driennym, domu nocnym. Ciało człowieka jest domem dla duszy, jest zarówno delikatna, krucha, jak i trwałą konstrukcja, jest medium, przez które przemawiają siły twórcze, jest wreszcie świątynią zamieszkiwaną przez duszę. Kiedy ciało pod wpływem upływającego czasu i doświadczeń życiowych zaczyna niedomagać, człowiek próbuje poszukiwać sensu życia w tej wiecznej podróży od narodzin aż do śmierci, rozumianych jako bieguny ludzkiego istnienia. Kreowany w powieści Tokarczuk świat jest płynny i organiczny, jest mieszanką głosów i wątków narracyjnych, które mają niemały wpływ na czytelnika i skłaniaja go do refleksji na temat ludzkiej kondycji i życia w ogóle. Podczas lektury niemal wszystkich utworów pisarki można odnieść wrażenie, że człowiek nieustannie ucieka od świata i od samego siebie, poszukuje odskoczni od codziennych dramatów, od rygoru narzucanego przez historię, biologię i obiektywny upływ czasu - jest to ucieczka częściowo celowa, a częściowo nieświadoma, powodowana stylem życia i wymogami współczesnej cywilizacji.

Widoczny w Biegunach fragmentaryzm, jako strategia narracyjna a zarazem sposób ukazania wizji życia i świata, jest jedną z podstawowych cech twórczości Olgi Tokarczuk. Jest on wynikiem „świadomości epizodycznej”, którą autorka postrzega przez analogię do sposobu widzenia świata przez owady - przedstawiane w utworze obrazy to ułamki całości, które dopiero muszą zostać uformowane w spójną całość (Wolny-Hamkało 2012). Pisarka ma raczej kwantowy stosunek do życia - przeszłość, teraźniejszość i przyszłość współistnieją w wiecznej teraźniejszości, przez co próba pokazania obrazu świata w formie linearnej jest czymś nienaturalnym, anachronicznym i nie odzwierciedla bieżących potrzeb narracji. Tradycyjnie pojmowana powieść zdaniem Tokarczuk - jest tworem sztucznym, ponieważ próbuje przełożyć mozaikowy obraz świata w sposób sukcesywny i chronologiczny, a nie z perspektywy panoramicznej. Ten wyższościowy, wielowymiarowy punkt widzenia jest charakterystyczny dla wszystkich powieści noblistki. W Domu dziennym, domu nocnym, jednym z najpiękniejszych dzieł Tokarczuk, pisze ona w sposób nieco elegijny o istnieniu i kondycji ludzkiej, porusza się między mitem a rzeczywistością, między czasem obiektywnym a subiektywnym. Prowadzona narracja skłania do refleksji na temat współczesnego człowieka, kruchości życia, piękna istnienia w jego wszelkich przejawach. Ten złożony, polifoniczny i poliwalentny utwór wprowadza czytelnika do czarującego 
świata, zamieszkiwanego przez całą rzeszę fascynujących postaci o niezwykle ciekawych, świetnie nakreślonych biografiach. Mimo bogactwa szczegółów narracja nie jest przeciążona, wprost przeciwnie - szczegóły ją dopełniają, a Dom dzৃienny, dom nocny odkrywa przed nami świat wpisany między sakralność a prozaiczność, w którym metafora jest na porządku dziennym. Tytułowa przenośnia łączy rzeczywistość i mistycyzm, światło i mrok, świat widzialny i niewidzialny. Wielość postaci, tworzących galerię niezwykłych portretów, jednych przedstawionych szczegółowo, innych - zwięźle, nie wywołuje bynajmniej poczucia przepełnienia świata narracyjnego, nie męczy i nie przeszkadza, respektuje bowiem aksjologiczny porządek dobrze przemyślany przez autorkę. W ten sposób pisarka zaprasza czytelnika do „prześwitującej rzeczywistości, do iluzorycznych światów i stanów granicznych w formie hipnagogicznych, zamglonych świadomości, bizarnych introspekcji lub złowieszczych przebłysków” (Dinu 2019), rzeczywistości przerywanej kodami „które czytelnik musi odkryć i odszyfrować, aby mógł zrozumieć przesłanie" (Diaconu 2018).

Wydaje się, że świat narracyjny utworów Olgi Tokarczuk istnieje zarówno w rzeczywistości znanej, rozpoznawalnej, jak i obcej, alegorycznej, zamieszkałej przez fascynujące, ale dziwne postaci. Taka jest też struktura jej ostatniej powieści przetłumaczonej na język rumuński pt. Prowadź swój pług prz̨ez. kości umarlych. Tytuł utworu - zapożyczony z wiersza Williama Blake’a Proverbs of Hell - nadaje fizycznej przestrzeni powieściowej wymiar etyczno-filozoficzny. Miejscem akcji jest miasteczko położone „na końcu świata”, na górskim, wietrznym płaskowyżu Kotliny Kłodzkiej, gdzie panują długie, przenikliwe zimy i gdzie zasięg telefonu kapryśnie wędruje między dwoma krajami. Jest to przestrzeń pozornie czarująca, a zarazem odludna, marginalna, rządzona przez prawa przyrody i zjawiska meteorologiczne, w której napastnikiem okazuje się człowiek, a nie zwierzę. W tym utworze Olga Tokarczuk zastosowała niezwykła, nieznaną nam dotąd formę narracji. Humanitarne przesłanie, etyczno-filozoficzne refleksje o życiu człowieka niszczącego ziemski ekosystem oraz przemyślenia na temat nadużyć, których się on dopuszcza, zawarła pisarka w formie powieści kryminalnej o akcencie feministycznym. Sama autorka określiła swoje dzieło jako thriller moralny (Tokarczuk 2017), egzystencjalny, mający na celu wszcząć alarm, zwrócić uwage na okrucieństwo współczesnego człowieka, który cierpi na „autyzm testosteronowy" i w polowaniach widzi ujście dla własnych frustracji, ale też sposób zaspakajania potrzeby dominacji. Za pośrednictwem głównej bohaterki Olga Tokarczuk apeluje o współczucie i prawo wszystkich istot do życia, 
stawia niewygodne pytania na temat wolnej woli w świecie pozbawionym zasad moralnych, a sama wchodzi w rolę rzecznika istot niemych, pozbawionych obrońcy, o które nie dba ani religia, ani społeczeństwo.

Janina Duszejko to typ bohatera sproblematyzowanego, złożonego i umiejętnie skonstruowanego, który umożliwia zadawanie niewygodnych pytań o naturę człowieka, społeczeństwo i współczesny system wartości, pytań może nieco przebrzmiałych, które jednak wymagaja ponownego namysłu. Decydując się na narrację pierwszoosobowa, autorka nie tylko panuje nad struktura tekstu, ale także kieruje wydarzeniami, sugeruje ich interpretację i aktywizuje czytelnika, skłaniając go do zajęcia stanowiska. Patrząc na rzeczywistość oczami Janiny, czytelnik dostrzega w ludziach „tyranów i uzurpatorów”, udawanych obrońców natury, którzy w istocie bezdusznie niszczą ekosystem. Kategoryczne podejście Janiny Duszejko, stanowczo opowiadającej się za tym, by mówić ludziom o tym, w co powinni wierzyć, gdyż w przeciwnym razie pojawi się ktoś, kto może ich zmanipulować umiejętnie prowadzonym dyskursem, przypomina zachętę Tokarczuk skierowaną do swoich rodaków w przeddzień wyborów parlamentarnych w 2019 roku, by głosować za demokracja. Poprzez zaangażowaną postawę bohaterki i jej odwagę w podejmowaniu działań mających na celu ochronę wartości, w które wierzy, pisarka z jednej strony demaskuje sztuczność relacji, z drugiej zaś pokazuje, jak cienka jest granica między walką o szczytne cele a fanatyzmem. Strategia autorki wydaje się skuteczna; Janina Duszejko jest osobą o wyraźnie określonych konturach, która symbiotycznie łączy w sobie cechy pozytywne i negatywne. Autodiegetyczny narrator pozwala na zwielokrotnione opisy przeżyć i obrazów świata. Monologi wewnętrzne bohaterki, które przerywaja linearny tok wywodu wspomnieniami z przeszłości, pogłębiają fabułę i uzupełniaja portret Janiny Duszejko. Formuła powieści sensacyjnej obfitującej w brutalne zbrodnie, których sprawcy zdają się nieludzcy, pozwala Tokarczuk na kreatywność, umożliwia takie manewrowanie formą, że dzieło w rzeczywistości bliskie jest różnym gatunkom literackim, stając się literaturą ambitna, która porusza ważne, aktualne problemy ontologiczne. W powieści zbrodnie stanowią jedynie punkt wyjścia do sformułowania zarzutów wobec ludzkości. Jak stwierdza autorka w jednym z wywiadów: „Napisać książkę tylko po to, aby dowiedzieć się, kim jest morderca, jest stratą papieru i czasu" (Armistead 2018). Czytając powieść, zauważamy, że tym, co przyciaga uwagę czytelnika, jest złożoność i oryginalność zarówno narratorki, jak i reszty pomniejszych, epizodycznych bohaterów - niektórych wrogich, antypatycznych, innych wręcz dziwnych, śmiesznych, ale i sympatycznych, 
wszystkich jednak dobrze skonstruowanych, prawdziwych i niezbędnych w strukturze dzieła. Warto również nadmienić, że postaci te nie występuja w utworze pod swoimi prawdziwymi nazwiskami, a mają symboliczne imiona, które oddają zarówno ich charakter, jak i alegoryczną strukturę tekstu. Możemy powiedzieć, że Prowadź swój plug pręez kości umarlych jest w równej mierze powieścią kryminalną, co apologia egzystencjalna.

Janina Duszejko nie akceptuje antropocentrycznego podejścia do świata. Jest zdania, że Ziemia nie została stworzona tylko dla człowieka, a rzeczywistość jest mozaiką równie ważnych, uzupełniających się elementów, które razem współtworzą porządek świata. Kiedy system ten zostaje naruszony, gdy jego równowaga zostaje zachwiana, Kosmos czuwa, gotowy powziąć odpowiednie działania. Obsesja głównej bohaterki na punkcie astrologii wyraża parametafizyczny punkt widzenia, wszechobecny we wszystkich utworach Olgi Tokarczuk, która patrzy na świat z perspektywy nadrzędnej wobec rzeczywistości. W Prowadź swój pług przęz kości umarlych człowiek zdaje się być istota, która tylko pozornie ma władzę nad własnym życiem, tak naprawdę „,na jego indywidualnym życiu odciska się niebo, jak pocztowa pieczęć z datownikiem na liście" i zamyka go w ziemskiej przestrzeni, przypisując mu „wytatuowany więzienny numer” (Tokarczuk 2009, 138). Jego przeznaczenie zapisane jest w gwiazdach, on sam został zaś rzucony na Ziemię, na której wszystko łączy się z sobą i gdzie wszyscy - zarówno ludzie, jak i zwierzęta - biora udział w ustawicznej walce dobra ze złem. Metafizyczny wymiar utworu, tak charakterystyczny dla prozy Tokarczuk, wraz z jego etyczno-filozoficznym przesłaniem wznoszą dzieło ponad formę literacką, jaka jest thriller. Gelu Diaconu widzi w Prowadź swój plug prz̨ez kości umarlych książkę, która pogłębia dychotomię człowiek - zwierzę (ci, którzy wyodrębnili człowieka z królestwa zwierząt, stawiając go na wyższym poziomie rozwoju, zapomnieli, że w rzeczywistości on także jest zwierzęciem, nierzadko mniej inteligentnym niż nieme stworzenia) i umiejętnie wysuwa na plan pierwszy kwestie dotyczące śmiertelności, przeznaczenia, praw natury vs. praw człowieka (zob. Diaconu 2018). Powieść ta jest kolejnym dowodem talentu literackiego Olgi Tokarczuk, urodzonej powieściopisarki, która swobodnie posługuje się różnymi gatunkami oraz stylami i zręcznie moduluje je tak, by przekazać proste, lecz refleksyjne obserwacje na temat życia i ludzkiej kondycji.

Sposób prowadzenia narracji w utworach Olgi Tokarczuk jest na tyle harmonijny, że proces przekładu staje się przyjemnością. Powieści pisarki nie stanowią w zasadzie problemu dla tłumacza, poza znalezieniem odpowiednich ekwiwalentów dla licznych nazw roślin i zwierząt, grzybów, insektów, terminów astro- 
logicznych czy poza trafnym oddaniem symboliki imion bohaterów. Samo wejście w rolę poszczególnych postaci i właściwe odczytanie przypisanej im w danym utworze funkcji jest niezwykle proste. Równie łatwo jest mówić głosem nadnarratora. Tokarczuk posługuje się żywym językiem, ale ma opinię pisarki niewygodnej, nie boi się bowiem podejmować kwestii aktualnych, lecz drażliwych. Feminizm, ekologia, globalizm, homoseksualizm, wegetarianizm, weganizm, przemieszczanie się i brak granic, obsesja podróży i nomadyzm współczesnego człowieka, prawa zwierząt, dyskryminacja osób w podeszłym wieku, stereotypy tożsamościowe - to tylko niektóre z tematów, które autorka porusza z całą powaga i, co ważniejsze, docierając do ich głębi.

Powieści noblistki są doceniane w Rumunii nie tylko ze względu na aktualną, choć kłopotliwa problematykę, którą podejmuja, ale nade wszystko za sprawą niesamowitej umiejętności przetransponowania przez pisarkę tych trudnych kwestii na język literatury. Jej utwory dowodza, że wartościowymi tematami literackimi moga być również zwyczajne sceny z codziennego życia; choć na pozór wydają się one banalne, to na kartach jej powieści nabieraja zupełnie innego znaczenia. Powieściopisarka, jak zgodnie twierdzą rumuńscy krytycy, ma poczucie humoru, barwny, wyrafinowany styl, wyjątkowy talent literacki, wnikliwy zmysł obserwacji oraz dar patrzenia na świat z wyższych perspektyw, bystry umysł zdolny do niespodziewanych, zaskakujących połączeń i interpretacji. Wszystko to sprawia, że Olga Tokarczuk jest niebywale popularna wśród rumuńskich czytelników.

\section{Literatura}

Cărtărescu M., 2002, Prz̧edmowa, w: Tokarczuk O., Străveacul și alte vremi, Bucureşti.

Godun C., 2013, Călătoria ca modus vivendi „Rătăcitorii” în România, w: Olteanu A., red., Omagiu profesorului Constantin Geambaşu la 65 ani, Bucureşti.

Godun C., 2018, Ipostaze ale eu-lui feminin in romanul „Ultimele povestiri” al Olgăi Tokarczuk, „Filologie Rusă", t. XXXIV, nr 2.

Tokarczuk O., 2004, Ostatnie historie, Kraków.

Tokarczuk O., 2007, Bieguni, Kraków.

Tokarczuk O., 2009, Prowadź swój plug pržez kości umarlych, Kraków.

\section{Netografia}

Armistead C., 2018, I was very naive. I thought Poland would be able to discuss the dark areas of our bistory' (Olga Tokarczuk), https://www.theguardian.com/books/2018/apr/20/olga-tokar czuk-interview-flights-man-booker-international [dostęp: 12.12.2019]. 
Cojocaru E., 2019, Rătăcitorii - Olga Tokarczuk, http://lecturile-emei.blogspot.com/2019/02/ ratacitorii-olga-tokarczuk.html [dostęp: 6.12.2019].

Diaconu G., 2018, Recen₹̨ie la „Rătăcitorï” de Olga Tokarczuk, https://omiedesem ne.ro/recenzie-ratacitorii-de-olga-tokarczuk/ [dostęp: 6.12.2019].

Dinu C., 2019, Un triptic despre stările de graniţăa, „Observator Cultural”, nr 983 [dostęp: 6.12.2019].

Godun C., 2019, Pledoaria pentru umanitate a Olgăi Tokarczuk în „Poartă-ți plugul peste oasele morților”, „Paragraf”, https://revistaparagraf.com/pledoaria-pentru-umanitate-a-olgai-tokarcz uk-in-poarta-ti-plugul-peste-oasele-mortilor/ [dostęp: 6.12.2019].

Muntean D., 2019, Clipești și deja e intuneric, Idem, Ca să poată veni vara, iarna trebuie povestită; Ibidem, Călătoresc, deci exist, https://deliamuntean.wordpress.com//?s=Olga+Tokarczuk\&sea rch=Mergi [dostęp: 12.12.2019].

Nicolae M., 2019, Poartă-ți plugul peste oasele morților, https://bookhub.ro/poarta-ti-plugul-pes te-peste-oase-peste-oasele-mortilor/ [dostęp: 12.12.2019].

Sora S., 2017, Casă de zi, casă de noapte. Un singur cer, https://pressone.ro/contributori/casa-dezi-casa-de-noapte-un-singur-cer/ [dostęp: 29.03.2018].

Stăvaru V., 2019, Călătorii în timp și spațiu, https://bookhub.ro/calatorii-in-timp-si-spatiu/ [dostęp: 12.12.2019].

Tokarczuk O., 2017, Fakt, że „Ksiegi...” sq tak czytane i komentowane, praywraca mi wiare w czytelnika, rozm. przepr. Antczak J., Śmigiel L., „Dziennik Zachodni”, https://plus.dziennikza chodni.pl/olga-tokarczuk-fakt-ze-ksiegi-sa-tak-czytane-i-komentowane-przywraca-mi-wiar e-w-czytelnika/ar/ c13-11795964 [dostęp: 6.12.2019].

Wolny-Hamkało A., 2012, Interview with Olga Tokarczuk on Bieguni ('Runners') NIKE prizewinner, https://web.archive.org/web/20120920101519/http://www.polishwriting.net/index.php? $\mathrm{id}=129$ [dostęp: 12.12.2019].

Cristina Godun - doc., Wydział Języków i Literatur Obcych, Departament Filologii Rosyjskiej i Słowiańskiej, Uniwersytet w Bukareszcie, Bukareszt, Rumunia.

Autorka podręczników do nauki języka polskiego oraz gramatyk języka polskiego dla rumuńskich studentów, a także słowników polsko-rumuńskich i licznych artykułów. Zajmuje się również tłumaczeniem literatury polskiej na język rumuński (30 pozycji, m.in. Dzienniki, Dramaty i Bakakaj Witolda Gombrowicza, Jadąc do Babadag, Fado, Dziewięć i Dojczland Andrzeja Stasiuka, Bieguni, Dom dzienny, dom nocny, Ostatnie historie i Prowadź swój pług przez kości umarłych Olgi Tokarczuk, Morfina Szczepana Twardocha). Jej główne zainteresowania badawcze to: dramat współczesny, literatura faktu i teoria przekładu.

Kontakt: cristina.godun@lls.unibuc.ro 